\title{
Performance of Fuzzy Inference System for Calorific Value Predicting by Using The Mamdani Method
}

\author{
Viska Inda Variani \\ Departement of Physics, Faculty of Mathematic and Natural Sciences, Halu Oleo University \\ Kampus hijau bumi tridharma, Anduonuhu, Kendari, 93232, Sulawesi Tenggara, Indonesia \\ Email: viskadhani@yahoo.co.id
}

\begin{abstract}
It is well known that the energy content of fuel is characterized by its calorific value which is usually measured by using a bomb calorimeter. In many analysis, the calorific value is usually related with the proximate analysis results. In this study, the calorific value predicting program based on the proximate analysis data using the fuzzy inference system with Mamdani method has been developed. In our analysis, the proximate analysis data of moisture and volatile matter contents are used as input and the calorific value as output. The results showed that the influence of the moisture content is more dominant in determining the calorific value of fuel than volatile matter content. The performance of the calorific value predicting program also shown that the prediction error is about $0.75 \%$ to $5.2 \%$. The obtained calorific value is well reproduced the experimental data.
\end{abstract}

Keywords: calorific value, moisture content, volatile matter content, fuzzy inference system, Mamdani method

\section{INTRODUCTION}

During the time, the world energy demand is increasing. This means that we need the sustainable and renewable energy. One of the alternative renewable energy is biofuel. The source of biofuel can be obtained from the biomass. Many researchers try to produce and characterize biofuel from some kind of biomass in order to find a biofuel with good quality for domestic cooking applications ${ }^{[1,2]}$. Biofuel quality might be described by its calorific value and proximate analysis results i.e. moisture, volatile matter, fixed carbon and ash contents.

The calorific value is the heat quantity of a unit weight of fuel after being completely burned. In general, the fuel quality depends on its energy content. And it well accepted that the biofuel energy content is characterized by the calorific value ${ }^{[3]}$. The high moisture content decrease the calorific value during combustion, since a big part of fuel energy are required for reducing moisture content. On the other hand, the high volatile matter content increase ignition process and combustion rate but it rise a more smoke ${ }^{[4,5]}$. At the end, the high fixed carbon content increase the calorific value because the remaining char after devolatilisation process is reacted with oxygen to release heat ${ }^{[1,3]}$. Ash is non-combustible element of biomass so its existence decrease the calorific value and combustion rate ${ }^{[6,7]}$.

The calorific value is usually measured by using a bomb calorimeter. The bomb calorimeter is a sophisticated experimental apparatus which requires expertise in its operation. Also the calorific value can be estimated based on proximate analysis and this procedure is more cheaper, easier and faster to conduct ${ }^{[8,9]}$. Therefore some researchers interested to find the mathematical model of relation between the calorific value and the proximate analysis 
results. Initially, the research object focused for predicting the calorific value of coal based on proximate analysis. Some of them applied multiple linear regression, artificial neural network and adaptive neuro-fuzzy inference system on their modelling ${ }^{[8,10,11,12]}$. Nowadays other researchers also predict the calorific value of biofuel based on proximate analysis result using equation linier and non linier and least square regression analysis ${ }^{[7,13]}$.

In our previous study, we used fuzzy inference system for developing the calorific value predicting program. In this program, the Tsukamoto method was chosen as method for fuzzy inference system ${ }^{[14]}$. We found that our program can explained the experimental caloric value quite satisfactory. However, many researcher have also used another method for the fuzzy inference system that is the Mamdani method ${ }^{[15]}$. This method has been proven that it can quite well explained the problem in many research areas such as engineering, agriculture and medical ${ }^{[15,16,17,18]}$. In this respect, we then developed the calorific value predicting program based on this method. We focus on investigating the performance of this program and compared the results with the ones obtained by program previously developed ${ }^{[14]}$.

\section{METHODS}

It is known that the fuzzy logic has three main steps i.e., fuzzification, fuzzy inference and defuzzification ${ }^{[19]}$. Fuzzification changes crisp values of input to fuzzy values. Each degree membership of the inputs is determined by membership function to appropriate with its fuzzy set. The fuzzy inference system is a method for interpreting the input values to the output values by some "if then" rule statements to formulate the conditional statements. In the fuzzy inference system, the methods which usually used are Tsukamoto, Mamdani and Sugeno methods. The aggregate result of fuzzy inference rule output is then counted in the defuzzification process. Centroid of gravity (COG), bisector, middle of maximum (MOM), largest of maximum (LOM), and smallest of maximum (SOM) are usually used.

We then develop the calorific value predicting program. In our progrsm, we use the shoulder function for fuzzification. While in the fuzzy inference system, Mamdani method is used. And in the defuzzifiction process, we use the COG method as the defuzzification formula.

\section{Fuzzification}

In the fuzzification process, the fuzzy variables, inputs and output, are divided into two fuzzy sets with high and low linguistic values. Membership degree of low is determined by left shoulder function while membership degree of high by right shoulder function (see Figure 2 for details). In our study, we use the proximate analysis data of moisture and volatile matter contents as input and the output is the calorific value.

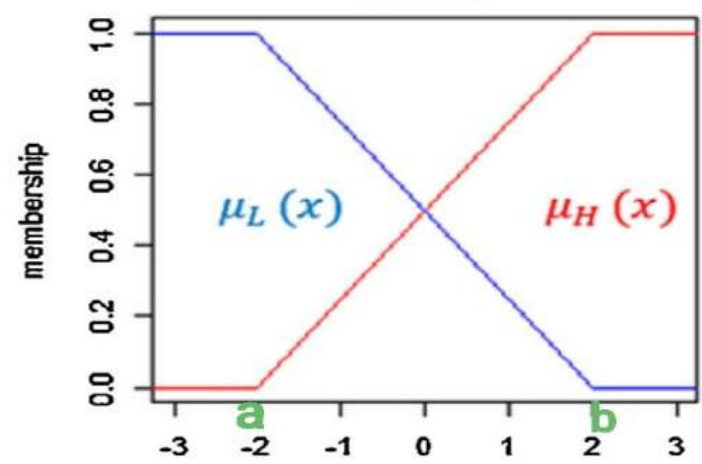

Figure 1. Shoulder curves as membership function ${ }^{[20]}$. 
Membership degree of low is define as

$$
\mu_{L}(x, a, b)=\left\{\begin{array}{c}
1, x \leq a \\
\frac{b-x}{b-a}, a<x<b, \\
0, x \geq b
\end{array}\right.
$$

and membership degree of high is given by

$$
\mu_{H}(x, a, b)=\left\{\begin{array}{c}
1, x \geq b \\
\frac{x-a}{b-a}, \quad a<x<b \\
0, x \leq a
\end{array}\right.
$$

In Eqs.(1) and (2), $\mu_{L}$ and $\mu_{H}$ are the membership degree of low and high, respectively. And $x, a, b$ are the crisp values.

\section{Fuzzy inference system using Mamdani method}

The Mamdani method is firstly introduced by Ebrahim Mamdani in $1975^{[15]}$. Mamdani method is also known as the Max-Min method. Function min is applied in implication process on antecedent and function max is applied in aggregation process on the consequent output of entire rules ${ }^{[21]}$.

In the fuzzy inference system, we set the rules to manage relation between antecedent and consequent. This relation should be connected with the appropriate experimental data. The fuzzy rules are given in Table 1. From Ref. [14], it is already defined the linguistic value of consequent output for the second and third rules. But we still have to define the linguistic value of consequent output for the first and fourth rules. Then we need to further investigate each linguistic value.

Based on the fuzzy inference rule output, we get four possibilities output of fuzzy inference rules as given in Table 2. In Mamdani method, function min is chosen as implication function to obtain alpha predicate $\left(\alpha_{1}, \alpha_{2}, \alpha_{3}, \alpha_{4}\right)$. Every $\alpha$-predicate is related to the linguistic value of consequent output. Function max is then applied to get the biggest $\alpha$-predicate for each linguistic value. At the end, we have $\alpha_{H}$ and $\alpha_{L}$ (See Table 2 for details).

\begin{tabular}{|c|c|c|c|c|c|c|c|}
\hline [R1] & \multirow{4}{*}{ IF } & $\begin{array}{c}\text { Moisture } \\
\text { content low }\end{array}$ & \multirow{4}{*}{ AND } & $\begin{array}{c}\text { Volatile Matter } \\
\text { content low }\end{array}$ & \multirow{4}{*}{ THEN } & $\begin{array}{c}\text { Calorific value } * \\
\text { high,low }\end{array}$ & $\alpha_{1}$ \\
\hline [R2] & & $\begin{array}{c}\text { Moisture } \\
\text { content high }\end{array}$ & & $\begin{array}{l}\text { Volatile Matter } \\
\text { content low }\end{array}$ & & $\begin{array}{c}\text { Calorific value } \\
\text { low }\end{array}$ & $\alpha_{2}$ \\
\hline [R3] & & $\begin{array}{c}\text { Moisture } \\
\text { content low }\end{array}$ & & $\begin{array}{l}\text { Volatile Matter } \\
\text { content high }\end{array}$ & & $\begin{array}{c}\text { Calorific value } \\
\text { high }\end{array}$ & $\alpha_{3}$ \\
\hline [R4] & & $\begin{array}{c}\text { Moisture } \\
\text { content high }\end{array}$ & & $\begin{array}{l}\text { Volatile Matter } \\
\text { content high }\end{array}$ & & $\begin{array}{c}\text { Calorific value } * \\
\text { high,low }\end{array}$ & $\alpha_{4}$ \\
\hline
\end{tabular}

Table 1. Fuzzy inference rule of the calorific value predicting program ${ }^{[14]}$

* It will be further investigated for each linguistic value 
Table 2. Implementation function max to determine the biggest alpha predicate

\begin{tabular}{lll}
\hline \multicolumn{1}{c}{ Possibility output of FIS } & Implementation function Max & $\begin{array}{c}\text { The biggest alpha } \\
\text { predicate }\end{array}$ \\
\hline $\mathbf{R}_{\mathbf{1}} \quad \mathbf{R}_{\mathbf{2}} \quad \mathbf{R}_{\mathbf{3}} \quad \mathbf{R}_{\mathbf{4}}$ & & $\alpha_{\mathrm{H}}$ and $\alpha_{\mathrm{L}}$ \\
\hline High Low High High $=\mathrm{HLHH}$ & $\alpha_{1}=\alpha_{\mathrm{H} 1}, \alpha_{2}=\alpha_{\mathrm{L} 1}, \alpha_{3}=\alpha_{\mathrm{H} 2}, \alpha_{4}=\alpha_{\mathrm{H} 3}$ & $\alpha_{\mathrm{H}}$ and $\alpha_{\mathrm{L}}$ \\
High Low High Low $=\mathrm{HLHL}$ & $\alpha_{1}=\alpha_{\mathrm{H} 1}, \alpha_{2}=\alpha_{\mathrm{L} 1}, \alpha_{3}=\alpha_{\mathrm{H} 2}, \alpha_{4}=\alpha_{\mathrm{L} 2}$ & $\alpha_{\mathrm{H}}$ and $\alpha_{\mathrm{L}}$ \\
Low Low High High $=\mathrm{LLHH}$ & $\alpha_{1}=\alpha_{\mathrm{L} 1}, \alpha_{2}=\alpha_{\mathrm{L} 2}, \alpha_{3}=\alpha_{\mathrm{H} 1}, \alpha_{4}=\alpha_{\mathrm{H} 2}$ & $\alpha_{\mathrm{H}}$ and $\alpha_{\mathrm{L}}$ \\
Low Low High Low $=\mathrm{LLHL}$ & $\alpha_{1}=\alpha_{\mathrm{L} 1}, \alpha_{2}=\alpha_{\mathrm{L} 2}, \alpha_{3}=\alpha_{\mathrm{H} 1}, \alpha_{4}=\alpha_{\mathrm{L} 3}$ &
\end{tabular}

The next step is aggregation process. The output fuzzy set that represent the output of each fuzzy inference rule are combined into a single output of fuzzy set. There are two possibilities of aggregation result as shown in Figure 2.

The intersection points, $\mathrm{z}_{\mathrm{L}}$ and $\mathrm{z}_{\mathrm{H}}$, is calculated as follows

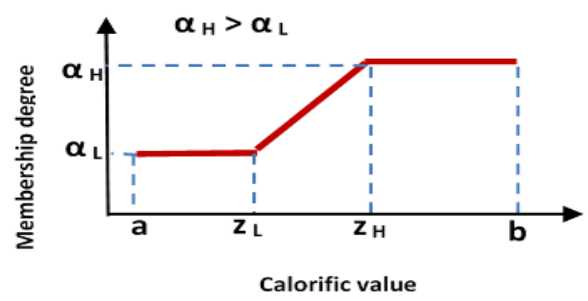

(a)

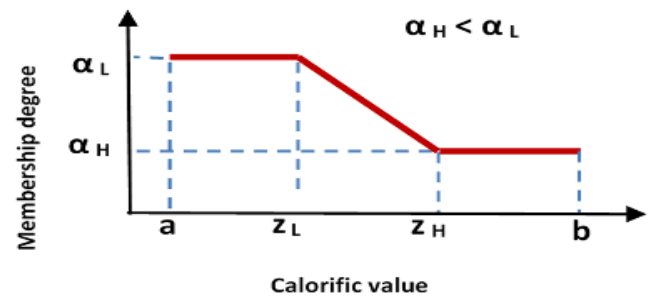

(b

Figure 2. Aggregation result

$$
z=\left\{\begin{array}{l}
a+\alpha(b-a) ; \alpha_{H}>\alpha_{L} \\
b-\alpha(b-a) ; \alpha_{H}<\alpha_{L}
\end{array}\right.
$$

\section{Defuzzification}

In the defuzzification process, we use the COG method. This method has already been proven to give the better results for predicting the early stage software development effort ${ }^{[20]}$. The equation of COG is given by ${ }^{[22]}$

$$
z=\frac{\int \mu(z) z d z}{\int \mu(z) d z}
$$

where $Z$ is the crisp value of the calorific value in our program.

\section{RESULT AND DISCUSSION}

In this section, we discuss the results of our study. We use the proximate analysis data to predict the calorific value in our program. We then compare the obtained calorific value with the one from measurement results using bomb calorimeter and other predicting method. Our design program is similar to the one previously developed ${ }^{[14]}$. The difference is in the fuzzy inference system where we used the Mamdani method. We also used the same experimental data, as given in Table 3. 
Table 3. Experimental data

\begin{tabular}{|c|c|c|c|c|}
\hline No. & Experimental Data & $\begin{array}{c}\text { MC } \\
\%\end{array}$ & $\begin{array}{c}\text { VM } \\
\% \\
\end{array}$ & $\begin{array}{c}C V \\
\text { Calorie/gr }\end{array}$ \\
\hline \multirow[t]{4}{*}{1} & Sabindo L.O et.al. data [23] & & & \\
\hline & Particle size 20 mesh & 11.62 & 12.78 & 5292.24 \\
\hline & 30 mesh & 10.84 & 12.92 & 5568.73 \\
\hline & 40 mesh & 8.45 & 13.28 & 6118.49 \\
\hline \multirow[t]{6}{*}{2} & Nurhilal O et.al. data [24] & & & \\
\hline & Composition $90 \%: 0 \%$ & 5.39 & 32.40 & 6211 \\
\hline & $80 \%: 20 \%$ & 5.61 & 33.15 & 5999 \\
\hline & $70 \%: 30 \%$ & 5.84 & 33.17 & 5935 \\
\hline & $60 \%: 40 \%$ & 6.11 & 33.36 & 5911 \\
\hline & $50 \%: 50 \%$ & 6.29 & 33.45 & 5824 \\
\hline \multirow[t]{7}{*}{3} & Sunardi et.al. data [3] & & & \\
\hline & Pressure $22,42 \mathrm{~kg} / \mathrm{cm}^{2} 40$ mesh & 6.91 & 21.28 & 5571.22 \\
\hline & 50 mesh & 7.82 & 21.30 & 5426.40 \\
\hline & 60 mesh & 8.95 & 21.32 & 5091.72 \\
\hline & Pressure $44,80 \mathrm{~kg} / \mathrm{cm}^{2} 40$ mesh & 6.18 & 21.30 & 5691.15 \\
\hline & 50 mesh & 7.22 & 21.33 & 5570.41 \\
\hline & 60 mesh & 8.12 & 21.35 & 5553.20 \\
\hline
\end{tabular}

Notes : $\mathrm{MC}=$ Moisture Content, $\mathrm{VM}=$ Volatile Matter, $\mathrm{CV}=$ Calorific Value

Based on fuzzy inference rules, we get four possibilities output of fuzzy inference rules that may represent phenomena in biofuel. In the evaluation process, we only took one possibility output of fuzzy inference rule which is closed to the experimental fact. As an example, we shown the evaluation process in Figure 3. The second data set of Sabindo et.al. ${ }^{[23]}$ is used.

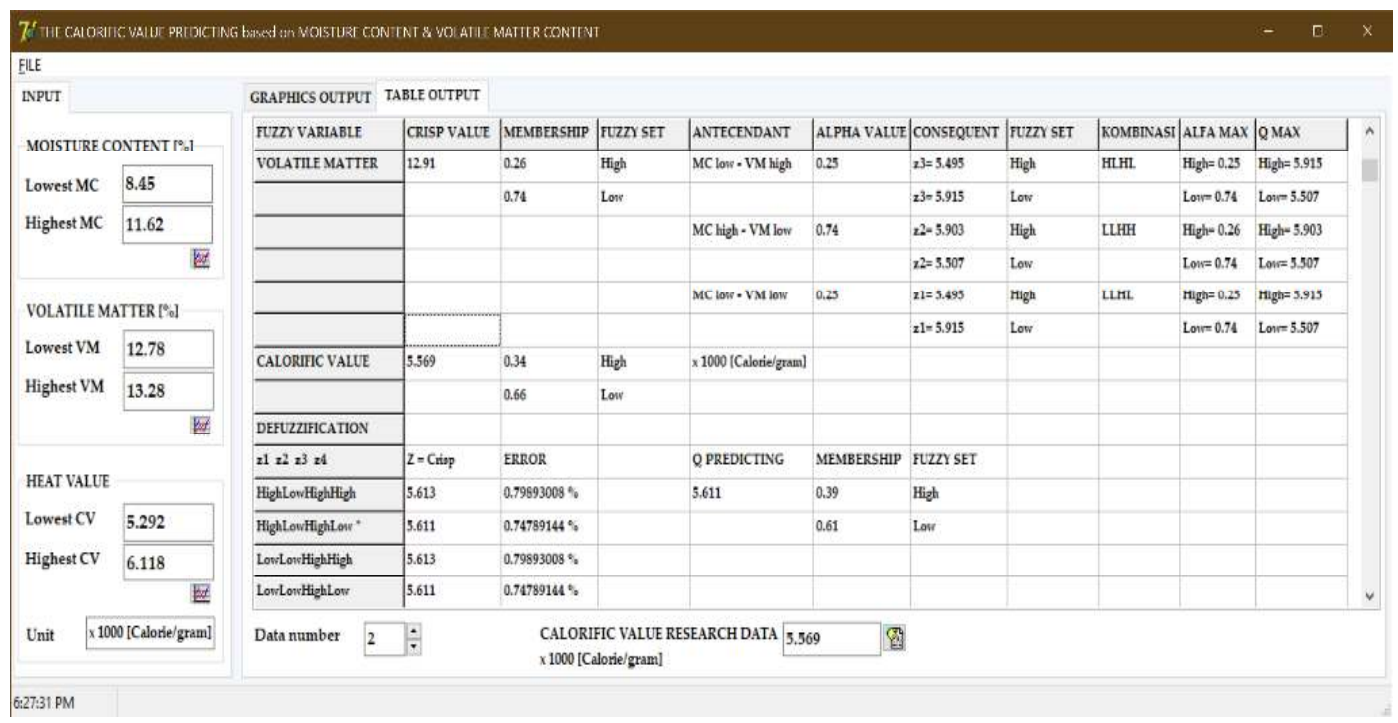

Figure 3. Example of the evaluation table

The prediction error of each possibility output of fuzzy inference rules is given. We choose the results of evaluation process with the smallest predictions values. In this process, we took the value of $0.75 \%$. Then we repeat the evaluation process using all experimental data set in ${ }^{[3][23][24]}$. The results are given in Table 4. 
Table 4. The evaluation result of the fuzzy inference rules output using Mamdani method

\begin{tabular}{|c|c|c|c|c|c|c|c|c|}
\hline \multirow[t]{2}{*}{$\begin{array}{l}\text { Experimental } \\
\text { data }\end{array}$} & \multirow[t]{2}{*}{ No. } & \multicolumn{3}{|c|}{$\begin{array}{l}\text { Linguistic value } \\
\text { with the biggest } \\
\text { membership degree }\end{array}$} & \multicolumn{4}{|c|}{$\begin{array}{c}\text { The smallest prediction error } \\
\%\end{array}$} \\
\hline & & MC & $\mathbf{V M}$ & CV & HLHH & HLHL & LLHH & LLHL \\
\hline \multirow{3}{*}{$\begin{array}{l}\text { Sabindo L.O } \\
\text { et.al. }{ }^{[23]}\end{array}$} & 1 & High & Low & Low & 5.20 & 5.20 & 5.20 & 5.20 \\
\hline & 2 & High & Low & Low & & 0.75 & & 0.75 \\
\hline & 3 & Low & High & High & 4.50 & 4.50 & 4.50 & 4.50 \\
\hline \multirow{5}{*}{$\begin{array}{l}\text { Nurhilal O } \\
\text { et.al. }{ }^{[24]}\end{array}$} & 1 & Low & Low & High & 2.08 & 2.08 & & \\
\hline & 2 & Low & High & High & & & 0.96 & 0.96 \\
\hline & 3 & 0.5 & High & 0.5 & & 1.39 & & 1.39 \\
\hline & 4 & High & High & Low & & 0.94 & & 0.94 \\
\hline & 5 & High & High & Low & & 2.21 & & 2.21 \\
\hline \multirow{6}{*}{$\begin{array}{l}\text { Sunardi } \\
\text { et.al. }{ }^{[3]}\end{array}$} & $1 \mathrm{a}$ & Low & High & High & 2.87 & 2.87 & & \\
\hline & $2 a$ & Low & 0.5 & High & 1.62 & 1.62 & & \\
\hline & $3 a$ & High & High & Low & & 3.14 & & 3.14 \\
\hline & $1 b$ & Low & Low & High & 0.81 & 0.81 & & \\
\hline & $2 b$ & High & High & Low & & 0.89 & & 0.89 \\
\hline & $3 b$ & High & High & Low & & 0.83 & & 0.83 \\
\hline \multicolumn{5}{|c|}{$\begin{array}{l}\text { The number of the smallest prediction error } \\
\text { that occurs on every composition }\end{array}$} & $\begin{array}{l}6 \\
\text { times }\end{array}$ & $\begin{array}{l}13 \\
\text { times }\end{array}$ & $\begin{array}{l}3 \\
\text { times }\end{array}$ & $\begin{array}{l}10 \\
\text { times }\end{array}$ \\
\hline
\end{tabular}

We see from Table 4 that the evaluation process for HLHL composition with the smallest prediction error appears 13 times from 14 data set. It means that the HLHL composition can represent the relation between the linguistic value of moisture and volatile matter contents with the calorific value. This results is similar to one obtained with calorific value predicting program using Tsukamoto method ${ }^{[14]}$. We also found that the relation of linguistic value based on the biggest membership degree of moisture and volatile matter contents with the calorific value is similar to the results based on Tsukamoto method. The calorific value is strongly influenced by moisture contents than volatile matter contents.

Table 5. Prediction of the calorific value with corresponding error

\begin{tabular}{|c|c|c|c|c|c|}
\hline No & \multirow{3}{*}{$\begin{array}{l}\text { Sabindo L.O } \\
\text { data [23] }\end{array}$} & $\begin{array}{c}\text { CV (Experiment) } \\
\text { Calorie/gr }\end{array}$ & $\begin{array}{c}\text { CV (prediction) } \\
\text { Calorie/gr }\end{array}$ & \multicolumn{2}{|c|}{$\begin{array}{c}\text { Prediction error } \\
\%\end{array}$} \\
\hline \multirow[t]{3}{*}{1} & & 5292.24 & $5567 \quad\left(5292.24^{*}\right)$ & 5.20 & $\left(0.00^{*}\right)$ \\
\hline & & 5568.73 & $5611 \quad\left(5572.37^{*}\right)$ & 0.75 & $\left(0.07^{*}\right)$ \\
\hline & & 6118.49 & $5843 \quad\left(6118.49^{*}\right)$ & 4.50 & $\left(0.00^{*}\right)$ \\
\hline \multirow[t]{5}{*}{2} & Nurhilal $\mathrm{O}$ & 6211 & $6082\left(6211.00^{*}\right)$ & 2.08 & $\left(0.00^{*}\right)$ \\
\hline & data [24] & 5999 & $6060\left(6073.85^{*}\right)$ & 1.02 & $\left(1.25^{*}\right)$ \\
\hline & & 5935 & $6018 \quad\left(6017.50^{*}\right)$ & 1.39 & $\left(1.39^{*}\right)$ \\
\hline & & 5911 & $5966\left(6017.50^{*}\right)$ & 0.94 & $\left(1.80^{*}\right)$ \\
\hline & & 5824 & $5953\left(5824.00^{*}\right)$ & 2.21 & $\left(0.00^{*}\right)$ \\
\hline \multirow[t]{6}{*}{3} & Sunardi et.al. & 5571.22 & $5411 \quad\left(5571.22^{*}\right)$ & 2.87 & $\left(0.00^{*}\right)$ \\
\hline & data $[3]$ & 5426.40 & $5338 \quad\left(5343.66^{*}\right)$ & 1.62 & $\left(1.52^{*}\right)$ \\
\hline & & 5091.72 & $5252 \quad\left(5091.72^{*}\right)$ & 3.14 & $\left(0.00^{*}\right)$ \\
\hline & & 5691.15 & $5645 \quad\left(5691.15^{*}\right)$ & 0.81 & $\left(0.00^{*}\right)$ \\
\hline & & 5570.41 & $5620\left(5619.41^{*}\right)$ & 0.89 & $\left(0.88^{*}\right)$ \\
\hline & & 5553.20 & $5599 \quad\left(5553.20^{*}\right)$ & 0.83 & $\left(0.00^{*}\right)$ \\
\hline
\end{tabular}

* taken from Ref.[14]. 
The HLHL composition obtained in the evaluation process is then used for testing the performance of our program. The experiment data in Table 3 is also used. The prediction results for caloric value are given in Table 5 in comparison with experimental data. The corresponding prediction error are also given. For comparison, we also shown the prediction error obtained by Tsukamato method ${ }^{[14]}$. It is clear that the Mamdani method can predict the experimental calorific value quite well as the results of Tsukamoto method. But if we compred more detail, it is found that the the prediction error of Mamdani is slightly larger than the error of Tsukamoto method. The Mamdani method gave an error of about $0.75 \%$ to $5.20 \%$ while the Tsukamoto method has an error of $0.00 \%$ to $1.52 \%$. Overall, the two methods can explained the experimental caloric value quit well with the accuracy more than $94 \%$. This mean that our program of the inference system based on Mamdani method can also be used for predicting the caloric value.

\section{CONCLUSION}

We have discussed the performance of the calorific value predicting program using fuzzy inference system using Mamdani method. We found that our analysis gave same conclusion with the one using Tsukamoto method ${ }^{[14]}$. It is also found that the calorific value is strong influenced by moisture than by volatile matter contents. The obtained of calorific value can well reproduced the experimental data as the one obtained by using Tsukamoto method. The difference is only in the prediction error value. The Mamdani method gave an error of 0.75 $\%$ to $5.20 \%$. This is slightly greater than the results of Tsukamoto method. Overall, the present program is quite appropriate for predicting the calorific value of the biomass.

\section{REFERENCES}

1 Gebrehiwot, G., Weldegebriel, D., \& G. Haileslassi. 2019. Production and characterization of biomass briquette from sawdust and cow dung admixture for domestic cooking applications in northern Ethiopia. Int. J. Renew. Energy Its Commer, Vol. 5, No. 2, pp. 49-57.

2 O. U. C, A. C. N, A. Samuel, \& S. J. E. 2017. Proximate analysis and performance evaluation of selected blends of biomass briquettes. J. enggineering Appl. Sci., vol. 10, pp. 144-161.

3 Sunardi, Djuanda, \& Mandra, M. A. S. 2019. Characteristics of charcoal briquettes from agricultural waste with compaction pressure and particle size variation as alternative fuel', Int. Energy J., vol. 19, no. 3, pp. 139-147.

4 Ajimotokan, H. A., Ehindero, A. O., Ajao, K. S., Adeleke, A. A., Ikubanni, P. P., \& Shuaib-Babata, Y. L., 2019. Combustion characteristics of fuel briquettes made from charcoal particles and sawdust agglomerates. Sci. African, Vol. 6.

5 Suryaningsih, S., Resitasari, R., \& Nurhilal, O., 2019. Analysis of biomass briquettes based on carbonized rice husk and jatropha seed waste by using newspaper waste pulp as an adhesive material. Journal of Physics: Conference Series.

6 Onukak, I. E., Mohammed-Dabo, I. A., Ameh, A. O., Okoduwa, S. I. R., \& Fasanya, O. O., 2017. Production and characterization of biomass briquettes from tannery solid waste. Recycling, Vol. 2, No. 17.

7 ÖzyuğUran, A., \& Yaman, S. 2017. Prediction of calorific value of biomass from proximate analysis. Energy Procedia, Vol. 107, pp. 130-136.

8 Feng, Q., Zhang, J., Zhang, X., \& Wen, S., 2015. Proximate analysis based prediction of gross calorific value of coals: A comparison of support vector machine, alternating 
conditional expectation and artificial neural network. Fuel Process. Technol.

9 Mandavgade, N. K., Jaju, S. B., \& Lakhe, R. R. 2012. Determination of uncertainty in gross calorific value of coal using bomb calorimeter. Int. J. Meas. Technol. Instrum. Eng, Vol. 1, No. 4, pp. 45-52.

10 Açikkar, M. \& Sivrikaya, O. 2018. Prediction of gross calorific value of coal based on proximate analysis using multiple linear regression and artificial neural networks. Turkish J. Electr. Eng. Comput. Sci.

11 Patel, S. U., Kumar, B. J., Badhe, Y. P., Sharma, B. K., Saha, S., Biswas, S., Chaudhury, A., Tambe, S.S., \& Kulkarni, B. D. 2007. Estimation of gross calorific value of coals using artificial neural networks. Fuel, Vol. 86, No. 3, pp. 334-344.

12 Rafezi, F., Jorjani, E., \& Karimi, S. 2011. Adaptive neuro-fuzzy inference system prediction of calorific value based on the analysis of US coals. Artif. Neural Networks - Ind. Control Eng. Appl., 169-182.

13 Erol, M., Haykiri-Acma, H., \& Küçükbayrak, S. (2010). Calorific value estimation of biomass from their proximate analyses data. Renewable energy, Vol. 35, No. 1, pp. 170173.

14 Variani, V. I. 2021. Calorific value predicting based on moisture and volatile matter contents using fuzzy inference system. Journal of Physics: Conference Series, Vol. 1825, No. 1, pp. 012006.

15 Mamdani, E. H., \& Assilian, S. 1975. An experiment in linguistic synthesis with a fuzzy logic controller. Int. J. Man. Mach. Stud, Vol. 7, No. 1, pp. 1-13.

16 Plebankiewicz, E. 2018. Model of predicting cost overrun in construction projects. Sustain, Vol. 10.

17 Mohammadi, A., Alimardani, R., Akbarnia, A., \& Akram, A. 2012 Modeling of draft force variation in a winged share tillage tool using fuzzy table look-up scheme. Agric. Eng. Int. CIGR J.

18 Moghbeli, F., Langarizadeh, M., Kiavar, M., Nikpajouh, A., \& Khatibi, T. 2018 Expert triage system in cardiology emergency department. Int. J. Comput. Sci. Netw. Secur, Vol. 18, No. 10.

19 Bhatnagar, R., kanti Ghose, M., \& Bhattacharjee, V. 2011. Selection of defuzzification method for predicting the early stage software effort using Mamdani FIS. Commun. Comput. Inf. Sci, Vol. 250, No. 9, pp. 375-381.

20 Jung, H. Y., Leem, S., Lee, S., \& Park, T. 2016. A novel fuzzy set based multifactor dimensionality reduction method for detecting gene-gene interaction. Comput. Biol. Chem. Vol. 65, pp. 193-202.

21 Sunjana. 2019. Prediction of production using the fuzzy mamdani inference method. Int. J. Adv. Sci. Technol, Vol. 28, No. 6, pp. 136-139.

22 Ayuningtias, L. P., Irfan, M., \& Jumadi, J. 2017. Analisa perbandingan logic fuzzy metode Tsukamoto, Sugeno dan Mamdani (Studi kasus: Prediksi jumlah pendaftar mahasiswa baru fakultas sains dan teknologi universita Islam Negri sunan Gunung Djati Bandung). J. Tek. Inform, Vol. 10, No. 1, Hal. 9-16.

23 Sabindo, L. O., Kadir., \& Hasbi, M. 2020. Pengaruh variasi ukuran mesh terhadap nilai kalor briket arang tempurung kelapa. Vol. 5, No. 1, pp. 1-8.

24 Nurhilal, O., \& Suryaningsih, S. 2018. Pengaruh komposisi campuran sabut dan tempurung kelapa terhadap nilai kalor biobriket dengan perekat molase. J. Ilmu dan Inov. Fis, Vol. 2, No. 1, pp. 8-14. 